\title{
Clinical and Laboratory Evaluation of Pediatric Tuberculosis Cases in Light of Nutritional Indicators
}

\author{
Pediatrik Tüberküloz Olgularının Klinik ve Laboratuvar \\ Özelliklerinin Nutrisyon Göstergeleri Eşliğinde Incelenmesi
}

\author{
Özlem Tezol', Mehmet Alakaya', Asuman Akar², Necdet Kuyucu² \\ ${ }^{1}$ Mersin Üniversitesi Tıp Fakültesi, Çocuk Sağlı̆̆ı ve Hastalıkları Anabilim Dalı, Mersin \\ ${ }^{2}$ Mersin Üniversitesi Tıp Fakültesi, Çocuk Enfeksiyon Hastalıkları Bilim Dalı, Mersin
}

\begin{abstract}
Objectives: Pediatric tuberculosis is a major public health problem. Malnutrition characterized with wasting is prevalent among pediatric tuberculosis patients. We aimed to review pediatric tuberculosis cases by considering their nutrition manifestations.

Materials and Methods: The study evaluated demographical, clinical, anthropometric, microbiological, histopathological and radiological characteristics of tuberculosis patients, retrospectively.

Results: The study involved 77 tuberculosis cases. Sixty-three percent of the patients were male with a mean age of $9.32 \pm 4.91$ years. Twenty-four patients (31\%) diagnosed with definite tuberculosis, thirtynine patients $(50 \%)$ with probable tuberculosis, and fourteen patients (18\%) with latent tuberculosis infection. Acid resistant bacteria were observed in $33 \%$, culture positivity was observed in $20 \%$, both acid resistant bacteria and culture positivity was observed in $45 \%$ of definite diagnosed group. Forty percent of patients had pulmonary, $32 \%$ had extrapulmonary, $6 \%$ had miliary, $2 \%$ had both pulmonary and extrapulmonary tuberculosis. Pulmonary tuberculosis diagnosed patients were significantly older than extrapulmonary plus miliary group $(\mathrm{p}=\mathrm{o} .003)$. Culture positivity rate was significantly higher in pulmonary, diagnostic histopathological sampling rate was significantly higher in extrapulmonary plus miliary group $(\mathrm{p}=0.019, \mathrm{p}=0.012)$. Thirty seven percent of patients had a contact history, $23 \%$ of those had household contact, and the most common index cases were fathers. The tuberculin test was positive in 11 patients $(45 \%)$ with definite and 15 patients $(38 \%)$ with probable tuberculosis. No significant difference has been observed between definite and probable tuberculosis groups according to the sex, average age, symptom duration, tuberculin test positivity, Bacille Calmette-Guerin vaccine scar presence, contact history rate, hematologic tests, and anthropometric measurements ( $>>0.05)$. At the time of diagnosis mean (SD) values of height for age and weight for height medians [ 94.35 (7.50) \% and $85.72(6.92) \%$, respectively] refered to mild malnutrition, the same conditions were remaining at the end of treatment. When height for age taken into consideration the chronic malnutrated group was probable tuberculosis group. Weight for height (for $<5$ years old cases) and body mass index (for $\geq 5$ years old cases) $\mathrm{Z}$ scores of sixteen patients were less than $-2 \mathrm{SD}$ value and these moderae malnutrated cases were remaining at the end of treatment. There was not a statistical significance between anthropometric measurements at the time of diagnosis and at the end of antituberculosis treatment ( $\mathrm{p}>0.05$ ).

Conclusion: Nutrition status monitoring, correcting nutritional deficiencies and failures can be neglected in course of antituberculosis treatment. Tuberculosis management should be integrated with malnutrition monitoring in pediatric cases.

Key words: child, malnutrition, tuberculosis
\end{abstract}

$\ddot{O} \mathbf{z}$

Amaç: Çocukluk çağı tüberkülozu önemli bir halk sağlığı sorunudur. Pediatrik tüberküloza sıklıkla zayıflık ile karakterize malnutrisyon eşlik eder. Bu çalıșmada pediatrik tüberküloz hastalarının nutrisyon göstergeleri eșliğinde değerlendirilmesi amaçlandı.

Materyal ve Metot: Tüberküloz tanısı almıș hastaların demografik, klinik, antropometrik, mikrobiyolojik, histopatolojik ve radyolojik özellikleri geriye dönük olarak incelendi.

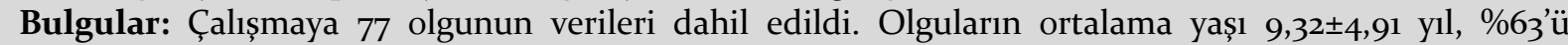
erkekti. Kesin tüberküloz tanısı alan 24 (\%31), olası tüberküloz tanısı alan 39 (\%50) ve latent tüberküloz tanısı alan $14(\% 18)$ hasta vardı. Kesin tanılı grupta olguların \%33’ünde aside dirençli bakteri görüldü, 
\%2o'sinde kültür pozitifti, \%45’inde hem aside dirençli bakteri görüldü hem kültür pozitifti. Olguların \%40’ı akciğer, \%32'si akciğer dıșı, \%6’sı miliyer, \%2'si akciğer ve akciğer dıșı tüberküloz birlikteliğiydi. Akciğer tübekülozu tanılı hastaların yaş ortalaması akciğer dıșı + miliyer tüberküloz tanılı hastaların yaş ortalamasından anlamlı olarak daha büyüktü $(\mathrm{p}=0,003)$. Kültür pozitifliği oranı akciğer tüberkülozu grubunda, tanısal histopatolojik örnekleme oranı akciğer dışı + miliyer tüberküloz grubunda daha yüksekti $(\mathrm{p}=0,019, \mathrm{p}=0,012)$. Temas öyküsü oranı \%37, ev içi temas oranı \%23 olarak saptandı, en sık indeks vakalar babalardı. Tüberkülin deri testi kesin tüberküloz tanılı 11 hastada (\%45), olası tüberküloz tanılı 15 hastada (\%38) pozitifti. Kesin ve olası tüberküloz grupları arasında cinsiyet, ortalama yaş, yakınma süresi, tüberkülin testi pozitifliği, Bacille Calmette-Guerin skarı varlığı, temas öyküsü oranı, hematolojik testler ve antropometrik ölçümler açısından anlamlı farklılık yoktu (p>0,05). Olguların tanı anında yașa göre boy median yüzde değerlerinin ortalaması $(94,35 \pm 7,50)$ ve boya göre ağırlık median yüzde değerlerinin ortalaması $(85,72 \pm 6,92)$ hafif malnutrisyonu göstermekteydi ve bu durum tedavi bitiminde de devam etmekteydi. Yaşa göre boy dikkate alındığında kronik malnutre olan grup olası tüberküloz grubuydu, bu grupta yakınma süresi ortancası 3 aydı. Boya göre ağırlık (<5 yaş hastalar için) ve vücut kitle indeksi ( $\geq 5$ yaş hastalar için) Z skoru -2 standart sapma değerinden düşük olan 16 hasta (\%25) vardı ve orta derecede malnutre olan bu olguların tedavi bitiminde de aynı kaldığı görüldü. Hem kesin hem olası tüberküloz grubunda tanı anındaki ve tedavi bitimindeki antropometrik ölçümler arasında istatistiksel olarak anlamlı fark yoktu ( $\mathrm{p}>0,05)$.

Sonuç: Pediatrik tüberküloz hastalarının nutrisyon durumlarının izlenmesi, antitüberküloz tedavi ile birlikte beslenme eksikliklerinin ve hatalarının giderilmesi ihmal edilebilmektedir. Çocuklarda tüberküloz yönetimi ile malnutrisyon izlemi bütünleștirilmelidir

Anahtar Kelimeler: çocuk, malnutrisyon, tüberküloz

\section{Yazıșma Adresi / Correspondence:}

Dr. Özlem Tezol

Mersin University Faculty of Medicine, Department of Pediatrics, Mersin

e-mail: ozlemtezol@hotmail.com

Date of submission: 30.10 .2018

Date of admission: 26.12 .2018

\section{Introduction}

Tuberculosis (TB) has been a threat to public health since ancient times and remains a major health problem, especially in underdeveloped countries. According to the Global Tuberculosis Report 2017 of the World Health Organization (WHO), 10.4 million new cases of TB were reported in 2016, of which $10 \%$ constituted pediatric patients under 15 years of age. In WHO report, the estimate of TB incidence in children aged o-14 years in Turkey was 1.5 per thousand. ${ }^{1}$ According to WHO a definite diagnosis of TB in children under 15 years old is made based on smear positivity. However, in this age group the number of bacilli is low and approximately $95 \%$ of cases under 12 years of age have smear-negative results. Therefore, pediatric cases are evaluated as definite and probable TB. A standard case definition for childhood TB is not available, so no true burden of disease can be detected in children. ${ }^{2}$

Pediatric TB cases are the most important indicators of the effectiveness of TB control programs in adults and is more commonly seen in countries with low- and middleincome economies. TB can lead to inadequate nutrition, but at the same time malnutrition increases the risk of TB. In 22 countries with a high disease burden, $26 \%$ of all TB cases have been associated with malnutrition. ${ }^{3}$ The difficulty in accessing health services, poverty, crowded living conditions, and malnutrition are directly related to the increase in TB incidence. ${ }^{2}$

Due to the inadequacy of effective control programs, poverty, war, migration, and increased incidence of HIV infection, it is difficult to prevent or manage TB. 
Epidemiological data of pediatric TB is important for the success of national control programs. $^{2}$ In this study, children with definite, probable or latent TB were evaluated in light of nutritional indicators.

\section{Materials and Methods}

In this study, the data of 77 patients diagnosed with TB in the Department of Pediatric Infectious Diseases between October 2007 and January 2017 were evaluated, retrospectively. The patients' data were screened to assess demographic characteristics, contact history, anthropometric measurements, clinical symptoms and findings, tuberculin skin test (TST) results, biochemical, radiological, microbiological, histopathological examinations, as well as diagnostic and treatment records.

Pulmonary TB diagnosis based on symptoms of cough and persistent unexplained

fever lasting for more than two weeks, weight loss, TST positivity, as well as a history of contact with an adult with TB diagnosis, the presence of radiological findings suggesting TB were included in the study. Extrapulmonary TB diagnosis based on the manifestation of pleurisy, lymphadenitis, osteomyelitis, arthritis, meningoencephalitis, and peritonitis, or the presence of plaque-like lesions on the skin. Based on the clinical signs and symptoms indicating multiple organ involvement, miliary TB diagnosed cases included in the study. Patients with both pulmonary and lymph node involvement were considered as pulmonary and extrapulmonary TB cases. Lastly, the data from asymptomatic cases with latent TB presenting with normal chest radiography and TST positivity were examined.

In the pulmonary TB cases, acid-resistant bacilli (ARB) were screened in the fasting gastric fluid (FGF) or sputum by Ziehl-Neelsen staining, and specimens cultured in the buffered Löwenstein-Jensen medium were examined. In the miliary and extrapulmonary TB cases, the results of microbiological and histopathological evaluation of tissue samples were investigated. For TST, o.1 ml of Pürified Protein Derivative solution was intradermally delivered into the inner surface of the forearm, and after 72 hours, the transverse diameter of induration was measured in millimeters. TST positivity was considered as a diameter of $\geq 10 \mathrm{~mm}$ in patients with previous Bacillus Calmette-Guerin (BCG) vaccination and $\geq 15 \mathrm{~mm}$ in those without BCG vaccination. 4

A household contact was defined as someone that shared the same enclosed space with the index case for $\geq 1$ nights or for frequent and extended periods over three months. ${ }^{5}$ The patients, whose family member was identified as an index case or who previously had contact with individuals diagnosed with TB were considered as having contact history.

The definite TB group consisted of patients with the presence of ARB in the FGF, sputum, tissue sample or cerebrospinal fluid, and/or Mycobacterium tuberculosis in the Löwenstein-Jensen medium. The probable TB cases were those that had negative ARB and culture results but met at least two of the following criteria: cough and/or fever that lasted more than two weeks, weight loss, TST positivity, contact history, and other clinical and radiological findings suggesting TB. ${ }^{6}$

Heights and body weights previously measured using standard anthropometric methods were recorded from the patient files. Based on the standard anthropometric 
measurements of WHO, the median percentages of height-for-age (HFA) and weightfor-height (WFH) were calculated. Malnutrition was evaluated as mild if the median HFA was 90-94\%, moderate if $\mathrm{HFA}=85-89 \%$, and severe if $\mathrm{HFA}<85$. For the median WFH values, $80-89 \%$ indicated mild malnutrition, 70-79\% moderate malnutrition, and $<70 \%$ severe malnutrition. Furthermore, according to the Waterlow classification, malnutrition was considered to be chronic if HFA was less than 95\%, and acute if WFH was less than $90 \%$. For patients younger than five years, the number of cases with a WFH Z score less than the -2 standard deviation (SD) value, for patients older than five years, the number of cases with a body mass index (BMI) Z score less than the $-2 \mathrm{SD}$ value were determined as moderate malnutrition. ${ }^{7}$ The anthropometric measurements at the time of diagnosis and at one month after completed treatment were compared.

Statistical analysis performed by using SPSS 21.0 package programme.Percentages, mean (SD) and median (min-max) values were given as descriptive statistics. Student t-test or Mann-Whitney U testwere used for comparison of two independent groups. Independent three groups are compared by One-way ANOVA or Kruskal-Wallis tests. The homogeneity of variance test was used. Categoric variables were compared by using Pearson chi-square test. The results were considered statistically significant if $P$ values were less than .05. This study was approved by Ethics Comittee of Mersin University (2017/15).

\section{Results}

The study involved 77 tuberculosis cases. Sixty three percent of the patients were male with a mean age of $9.32 \pm 4.91$ years. Twenty nine (37\%) patients had contact history. Single BCG scar was detected in $32(41 \%)$ patients. Thirty one patients $(40 \%)$ were diagnosed with pulmonary, 25 patients $(32 \%)$ with extrapulmonary, 5 patients $(6 \%)$ with miliary, 2 patients ( $2 \%$ ) with pulmonary and extrapulmonary, 14 patients $(18 \%)$ with latent tuberculosis. Cervical lymph node involvement was existent in pulmonary and extrapulmonary TB. Pulmonary and meningeal involvement was observed in four patients and pulmonary, hepatic, splenic involvement was observed in one patient among miliary TB cases (Table 1).

TabIe 1. Demographic and clinic characteristics of pediatric tuberculosis patients

\begin{tabular}{|l|c|c|}
\hline & Patient (n) & $\%$ \\
\hline Female & $28 / 77$ & 36.36 \\
\hline Male & $49 / 77$ & 63.63 \\
\hline Age & & \\
o-4 years & $18 / 77$ & 23.37 \\
5-14 years & $59 / 77$ & 76.62 \\
\hline Weight for height Z score <-2 SD & $6 / 63$ & 9.52 \\
Body mass index Z score <-2 SD & $10 / 63$ & 15.87 \\
\hline Clinical symptoms and findings & $31 / 63$ & 49.20 \\
Cough & $31 / 63$ & 49.20 \\
Fever & $18 / 63$ & 28.57 \\
Weight loss & $16 / 63$ & 25.39 \\
Malaise & $13 / 63$ & 20.63 \\
Night sweat & & \\
\hline
\end{tabular}




\begin{tabular}{|c|c|c|}
\hline $\begin{array}{l}\text { Expectorating } \\
\text { Stomach ache } \\
\text { Decreased breathing sounds } \\
\text { Pulmonary rale } \\
\text { Wheezing } \\
\text { Vomiting } \\
\text { Servical tubercle } \\
\text { Head ache } \\
\text { Haemoptysis } \\
\text { Convulsion } \\
\text { Lumbar pain } \\
\text { Axillary tubercle } \\
\text { Gait disturbance } \\
\text { Focal neurological finding } \\
\end{array}$ & $\begin{array}{l}13 / 63 \\
10 / 63 \\
10 / 63 \\
8 / 63 \\
6 / 63 \\
6 / 63 \\
6 / 63 \\
5 / 63 \\
4 / 63 \\
4 / 63 \\
3 / 63 \\
2 / 63 \\
2 / 63 \\
1 / 63 \\
\end{array}$ & $\begin{array}{l}20.63 \\
15.87 \\
15.87 \\
12.69 \\
9.52 \\
9.52 \\
9.52 \\
7.93 \\
6.34 \\
6.34 \\
4.76 \\
3.17 \\
3.17 \\
1.58 \\
\end{array}$ \\
\hline $\begin{array}{l}\text { Contact history } \\
\text { Yes } \\
\text { Household contact 0-4 years } \\
\text { Household contact 5-14 years } \\
\text { Out-of-home contact } \\
\text { None }\end{array}$ & $\begin{array}{l}29 / 77 \\
8 / 29 \\
10 / 29 \\
11 / 29 \\
48 / 77\end{array}$ & $\begin{array}{l}37.66 \\
10.38 \\
12.98 \\
14.28 \\
62.33 \\
\end{array}$ \\
\hline $\begin{array}{l}\text { Index case } \\
\text { Father } \\
\text { Sibling } \\
\text { Grandfather } \\
\text { Uncle } \\
\text { Mother } \\
\text { Grandmother } \\
\text { Cousin }\end{array}$ & $\begin{array}{l}8 \\
5 \\
5 \\
4 \\
3 \\
2 \\
2 \\
\end{array}$ & $\begin{array}{c}27.58 \\
17.24 \\
17.24 \\
13.79 \\
10.34 \\
6.89 \\
6.89\end{array}$ \\
\hline $\begin{array}{l}\text { BCG scar } \\
\text { Presence } \\
\text { Absence }\end{array}$ & $\begin{array}{l}32 / 77 \\
45 / 77\end{array}$ & $\begin{array}{r}41.55 \\
58.44 \\
\end{array}$ \\
\hline $\begin{array}{l}\text { Tuberculin skin test } \\
\text { Positive } \\
\text { Negative }\end{array}$ & $\begin{array}{l}40 / 77 \\
37 / 77\end{array}$ & $\begin{array}{l}51.94 \\
48,05\end{array}$ \\
\hline $\begin{array}{l}\text { Diagnosis } \\
\text { Pulmonary TB } \\
\text { Definite } \\
\text { Probable } \\
\text { Extrapulmonary TB } \\
\text { Definite TB lymphadenitis } \\
\text { Probable TB lymphadenitis } \\
\text { Definite CNS tuberculosis } \\
\text { Probable CNS tuberculosis } \\
\text { Definite TB pleuritis } \\
\text { Probable TB pleuritis } \\
\text { Definite TB osteomyelitis } \\
\text { Probable TB osteomyelitis } \\
\text { Definite TB arthritis } \\
\text { Probable TB arthritis } \\
\text { Probable skin TB } \\
\text { Miliary TB }\end{array}$ & $\begin{array}{l}31 \\
15 \\
16 \\
25 \\
3 \\
5 \\
1 \\
6 \\
1 \\
4 \\
1 \\
1 \\
1 \\
1 \\
1 \\
5\end{array}$ & $\begin{array}{l}40.25 \\
19.48 \\
20.77 \\
32.46 \\
3.89 \\
6.49 \\
1.29 \\
7.79 \\
1.29 \\
5.19 \\
1.29 \\
1.29 \\
1.29 \\
1.29 \\
1.29 \\
6.49 \\
\end{array}$ \\
\hline
\end{tabular}




\begin{tabular}{|l|c|c|}
\hline Lung, CNS & 4 & 5.19 \\
Lung, liver, spleen & 1 & 1.29 \\
Pulmonary and extrapulmonary TB & 2 & 2.59 \\
Latent TB & 14 & 18.18 \\
\hline Positive diagnostic tests & & \\
ARB & $8 / 24$ & 33.33 \\
Fasting gastric fluid & 2 & 8.33 \\
Lymph node & 3 & 12.50 \\
Bony tissue & 1 & 4.16 \\
Joint liquid & 1 & 4.16 \\
Cerebrospinal fluid & 1 & 4.16 \\
Culture & $5 / 24$ & 20.83 \\
Sputum & 3 & 12.50 \\
Fasting gastric fluid & 1 & 4.16 \\
Pleura & 1 & 4.16 \\
ARB + culture & $11 / 24$ & 45.83 \\
Sputum & 6 & 25.00 \\
Fasting gastric fluid & 5 & 20.83 \\
\hline Histopathology & & \\
Lymph node & $10 / 25$ & 40.00 \\
Pleura & $5 / 25$ & 20.00 \\
Lung parenchyma & $3 / 31$ & 9.67 \\
Bone & $2 / 25$ & 8.00 \\
Periton & $1 / 25$ & 4.00 \\
Skin & $1 / 25$ & 4.00 \\
\hline Radiological findings & & 69.76 \\
Patchy consolidation/nodular opacites & $30 / 43$ & 55.81 \\
Mediastinal or hilar lymphadenopathies & $24 / 43$ & 27.90 \\
Cavitary lesion & $12 / 43$ & 20.93 \\
Pleural effusion & $9 / 43$ & 16.27 \\
Budding tree view & $7 / 43$ & 9.30 \\
Lobar consolidation & $4 / 43$ & 4.65 \\
Pneumothorax & $2 / 43$ & \\
\hline SD, & 13 . & \\
\hline
\end{tabular}

SD, standard deviation; BCG, Bacille Calmette-Guerin vaccine; TB, tuberculosis; CNS, central nervous system; ARB, acid-resistant bacilli

Among 24 patients with definite TB diagnosis ARB was positive in 8 (33\%), culture was positive in $5(20 \%)$, both ARB and culture were positive in $11(45 \%)$ microbiologic samples. Chronic granulomatous inflammation and/or caseous necrosis determined by examining 3 lung tissue and 19 extra-lung tissue samples. Patch/nodular consolidation $(69 \%)$ was the most common radiologic finding in pulmonary imaginations (Table 1$)$. Bilateral sacroiliac joint involvement determined in TB arthritis patient while unilateral femur involvement determined in TB osteomyelitis patients. Tuberculomas were demonstrated in 4, basilar involvement and hidrocephalus were demonstrated in 3 patients with CNS tuberculosis. The most common symptoms and findings were cough and fever (Table 1).

At the time of diagnosis means of HFA $(94,35 \pm 7,50 \%)$ and WFH $(85,72 \pm 6,92 \%)$ refered to mild malnutrition, the same conditions were remaining at the end of treatment. Means of HFA and WFA median percentages were pointing out mild chronic and mild acute malnutrition in probable TB group at the time of diagnosis and 
this status was remaining one month after the complation of treatmet. In definite TB patients mean HFA median percentage was normal, mean WFA median percentage was pointing out mild acute malnutrition at the time of diagnosis and this status was remaining one month after the complation of treatmet. Six patients' (9\%) WFA Z scores were less than -2 SD value, 10 patients' (15\%) BMI Z scores were less than -2 SD value and it was noticed that these moderately malnourished patients' statuses were persisted after the the completed treatmet. Mean values of median percentages increased statistical insignificantly ( $\mathrm{p}=0.246$ for HFA, $\mathrm{p}=0.173$ for WFA). Mean antropometric values of definite and probable TB groups were statistically similar (Table 2).

Table 2. Characteristics of patients diagnosed with definite, probable and latent tuberculosis; nutrition indicators and laboratory findings of definite and probable tuberculosis cases

\begin{tabular}{|c|c|c|c|c|}
\hline & $\begin{array}{c}\text { Definite TB } \\
(\mathrm{n}=24)\end{array}$ & $\begin{array}{c}\text { Probable TB } \\
(n=39)\end{array}$ & $\begin{array}{c}\text { Latent TB } \\
(n=14)\end{array}$ & $\mathbf{p}$ \\
\hline Age (year) & $11.14 \pm 5.17$ & $8.16 \pm 4.72$ & $8.66 \pm 5.13$ & $0.121^{*}$ \\
\hline Gender (female) & $7(\% 29)$ & $18(\% 46)$ & $5(\% 35)$ & 0.224 \\
\hline Symptom duration (month) & $2(1-5)$ & $3(1-12)$ & - & $0.910^{\dagger}$ \\
\hline Positive contact history & $10(\% 41)$ & $10(\% 25)$ & $9(\% 64)$ & 0.039 \\
\hline BCG scar presence & $10(\% 41)$ & $14(\% 35)$ & $8(\% 57)$ & 0.415 \\
\hline TST positivity & $11(\% 45)$ & $15(\% 38)$ & - & 0.599 \\
\hline Height for age (median \%) & & & & \\
\hline - At the time of diagnosis & $95 \cdot 57 \pm 6.88$ & $93.14 \pm 8.34$ & - & $0.493^{*}$ \\
\hline - At the end of treatment & $95 \cdot 92 \pm 6.21$ & $93.80 \pm 7.75$ & - & $0.243^{*}$ \\
\hline $\begin{array}{l}\text { Weight for height (median } \\
\% \text { ) }\end{array}$ & & & & \\
\hline - At the time of diagnosis & $86.59 \pm 6.41$ & $84.85 \pm 7.43$ & - & $0.106^{*}$ \\
\hline $\begin{array}{l}\text { - At the end of treatment } \\
\text { BMI }\left(\mathrm{kg} / \mathrm{m}^{2}\right)\end{array}$ & $88.29 \pm 7.16$ & $88.17 \pm 7.55$ & - & $0.348^{*}$ \\
\hline - At the time of diagnosis & $15.2 \pm 3.6$ & $14.5 \pm 2.9$ & - & 0.587 \\
\hline - At the end of treatment & $15.1 \pm 4.4$ & $14.6 \pm 3.8$ & - & 0.132 \\
\hline WFH and $\mathrm{BMI}<-2$ SD value & & & & \\
\hline - At the time of diagnosis & $4(\% 16)$ & $12(\% 30)$ & - & 0.087 \\
\hline - At the end of treatment & $4(\% 16)$ & $12(\% 30)$ & - & 0.088 \\
\hline Leucocyte $\left(\times 10^{3} / \mu \mathrm{L}\right)$ & $10.31 \pm 4.23$ & $11.26 \pm 4.81$ & - & $0.499^{*}$ \\
\hline Hemoglobin (g/dL) & $11.2 \pm 2$ & $11.5 \pm 1.7$ & - & $0.632^{*}$ \\
\hline $\mathrm{CRP}(\mathrm{mg} / \mathrm{L})$ & $35(5-112)$ & $13(2-45)$ & - & $0.167^{\dagger}$ \\
\hline Sedimentation $(\mathrm{mm} / \mathrm{h})$ & $45 \pm 30$ & $33 \pm 25$ & - & $0.116^{*}$ \\
\hline Platelet $\left(\times 10^{3} / \mu \mathrm{L}\right)$ & $400 \pm 153$ & $411 \pm 125$ & - & $0.782^{*}$ \\
\hline
\end{tabular}

BCG, Bacille Calmette-Guerin vaccine; TST, tuberculin skin test; WFH, weight for height; BMI, body mass index; SD, standard deviation; $\mathrm{CRP}, \mathrm{C}$-reaktive protein

${ }^{*}$ : data are mean $\pm \mathrm{SD},{ }^{\dagger}$ : data are median (min-max)

There were 7 females - 17 males in definite TB, 18 females-21 males in probable TB, 5 females - 9 males in latent TB group. The groups were similar in gender distrubition and age. Contact history rates were significantly different between definite, probable and latent groups $(\mathrm{p}=0.039)$, latent TB group had the highest rate. Contact history rates were similar in definite and probable TB groups $(\mathrm{p}=\mathbf{0 . 2 5 8})$. Definite and probable 
TB patients' symptome durations, BCG scar presences, TST positivities, leukocytes and platelet counts, hemoglobine, $\mathrm{C}$-reactive protein, and sedimentation rate values were statistically similar (Table 3 ).

Table 3. Characteristics of patients diagnosed with pulmonary and extrapulmonary tuberculosis

\begin{tabular}{|l|c|c|c|}
\hline & $\begin{array}{c}\text { Pulmonary TB } \\
(\mathbf{n = 3 1})\end{array}$ & $\begin{array}{c}\text { Extrapulmonary + } \\
\text { Miliary TB (n=30) }\end{array}$ & p \\
\hline Age (year) & $10.94 \pm 4.67$ & $6.82 \pm 4.75$ & $\mathbf{0 . 0 0 3}^{*}$ \\
Gender (female, \%) & $10(32)$ & $15(50)$ & 0.204 \\
Symptom duration (month) & $3(1-12)$ & $2(1-6)$ & $0.139^{\dagger}$ \\
Contact history positivity (\%) & $12(38)$ & $6(20)$ & 0.117 \\
TST positivity (\%) & $13(44)$ & $12(37)$ & 0.705 \\
Culture positivity (\%) & $12(41)$ & $3(10)$ & $\mathbf{0 . 0 1 9}$ \\
ARB positivity (\%) & $12(41)$ & $7(21)$ & 0.176 \\
Histopathologic sampling (\%) & $3(9)$ & $19(63)$ & $\mathbf{0 . 0 1 2}$ \\
BCG scar presence (\%) & $10(32)$ & $13(43)$ & 0.483 \\
\hline
\end{tabular}

TST, tuberculin skin test; ARB, acid-resistant bacilli; BCG, Bacille Calmette-Guerin vaccine ${ }^{*}:$ data are mean $\pm \mathrm{SD},{ }^{\dagger}$ : data are median $(\min -\mathrm{max})$

Mean age and culture positivity rate of pulmonary TB patients were significantly higher compared to extrapulmonary TB patients $(\mathrm{p}=0.003, \mathrm{p}=0.019)$. Histopathological sampling incidence was higher in extrapulmonary TB patients $(\mathrm{p}=0.012)$. Gender distrubitions, symptom durations, contact history rates, BCG scar presences, TST and ARB positivity rates were statistically similar between these groups (Table 3).

None of cases who had TB contact history had used Isoniasid (INH) neither before nor during admission. Probable pulmonary TB and probable, definite TB lymphadenitis cases were treated totally 6 months consisted of 2 months intensive phase with Pyrazinamide, INH, Rifampicin followed by INH, Rifampicin for 4 months. Definite pulmonary TB cases received 4 drug combination by adding Ethambutol in first 2 months of treatment. Extrapulmonary TB except TB lymphadenitis cases were treated totally 12 months consisted of 2 months with Pyrazinamide, INH, Rifampicin,Ethambutol or Streptomycine and INH, Rifampicin for 10 months. Miliary TB, CNS tuberculosis and TB peritonitis cases were administered 8-week steroid treatment in addition to initial anti-TB treatment. Patients with latent TB received INH prophylaxis for 6 months. A 9 year old male patient with HIV/TB co-infection who had recurrent pulmoner TB died. No drug resistance was determined. Neurologic sequelae was developed in 3 patients with CNS tuberculosis.

\section{Discussion}

Inadequate management of TB in adult patients makes pediatric TB a serious health problem since children are frequently infected with $M$. tuberculosis as a result of contact with adult TB patients. It is difficult to predict the global incidence of TB in children due to the lack of a standard clinical case definition and the difficulties in achieving a definite diagnosis. According to the 2017 WHO report, the number of 
children under 15 years diagnosed with TB was around one million in 2016. In the same report, Turkey wasn't among the countries with high TB incidence. ${ }^{1,2}$

In Turkey, a total of 584 pediatric TB cases were reported from 2005 to 2013 . Of these cases, $23 \%$ were aged between o and 4 years and $76 \%$ between 5 and 14 years. ${ }^{8}$ The results on the age distribution obtained in the current study are consistent with those reported throughout the country. In the literature, $62 \%$ of children diagnosed with TB were found to be under 6 years old and $49 \%$ under 5 years. ${ }^{9,10}$ The most common clinical symptoms of TB are cough, fever, night sweats, and weight loss, and the presence of any of these symptoms has a high sensitivity of $80 \%$ in identifying individuals to be further evaluated for TB. ${ }^{11}$ In the current study, the most common complaints were cough, fever, and weight loss, similar to the study by Tanır et al. ${ }^{12}$ The combination of cough, weight loss, and fatigue is considered to have a positive predictive power for TB in children over 5 years. ${ }^{13}$ In a study performed in Peru to describe the clinical picture of pediatric TB according to age groups, it was found that in older children, fainting, weight loss, and cough were common, but respiratory distress, hemoptysis and night sweat were less frequent, and in children younger than two years, cough and fever were frequent, but weight loss and lack of appetite were rare. In the same study, the duration of the symptoms before admission was longer than four weeks in $80 \%$ of children. ${ }^{14}$ The median duration of symptoms in our study was two months.

In children, a TB diagnosis is made based on close contact with an infected case, positive TST or interferon gamma release test, and presence of supporting physical examination or radiological findings. ${ }^{15}$ In the current study, $37 \%$ of the children had contact history. This percentage was previously reported to be $63 \%, 51 \%$, and $40 \%$ in different studies conducted throughout Turkey, and no association was found between contact history and a definite TB diagnosis. ${ }^{2,12,16}$ In contrast, in Italy, contact history was associated with development of pulmonary TB frequently. ${ }^{17}$ In the current study, the pulmonary TB group had a higher rate of contact positivity, but this difference was not statistically significant. An infectious adult most often infects infants and kids in the household. Wu et al. reported 31\% household contact among 1212 pediatric TB cases and associated household contact with severe TB in children. ${ }^{18}$ In this study, there were 15 cases ( $23 \%$ ) of household contact history, of which seven were in the $0-4$ age range, and the diagnoses were miliary TB in two cases, CNS TB in one case, and pulmonary TB in four cases. In a multicenter study performed in Turkey, the detection rate of index cases was 39\%, who mostly consisted of the fathers of the children. ${ }^{13}$ Based on a similar index case description, we also found that the fathers were the most frequent index cases.

In countries with a high prevalence of $\mathrm{TB}$, a single dose of $\mathrm{BCG}$ vaccine is recommended as soon as possible after birth. BCG has been shown to be effective in reducing the prevalence of disseminated TB types, such as miliary and meningeal TB in children. ${ }^{19}$ In Turkey, BCG vaccine is administered two months after birth. In our study, 27 patients (42\%) had a single BCG scar, compared to $22.9 \%$ of definite TB cases in Gencer et al., and $48.8 \%$ in a study conducted in Nepal. ${ }^{20,21}$ Furthermore, we found TST positivity as 51.5\%, similar to the previous rates reported in Turkey; $53.3 \% .^{11}$

Extrapulmonary TB is more frequent in children than in adults and seen in $25-35 \%$ of children with TB. Superficial lymph node involvement is the most common clinical 
form of extrapulmonary TB in children, with $63-77 \%$ of cases presenting with cervical lymph node involvement. ${ }^{22}$ In this study, the most common form of extrapulmonary TB was observed to be TB lymphadenitis, which comprised $66 \%$ unilateral cervical lymphadenitis cases.

CNS tuberculosis is the most serious complication in children due to mortality and high morbidity. TB meningitis is detected in $0.3 \%$ of untreated infant TB cases, most commonly in the 6 months- 4 years age group, and the risk of development of TB meningitis is higher in younger children. ${ }^{22}$ In the current study, all CNS TB cases were under 9 years old, with four ( $57 \%$ ) being under 4 years old. Diagnosis of TB meningitis is difficult and requires high clinical suspicion. The clinical course of the disease depends on the clinical stage at which the treatment is initiated. ${ }^{21}$ In our study all cases presented with second-stage disease manifestation at the time of admission. Prognosis was good in four cases whereas permanent neurological disorders developed in three cases.

Bone-joint TB accounts for $10-35 \%$ of extrapulmonary TB cases. The femur and tibia are most commonly involved in TB osteomyelitis. Weight-bearing joints, such as the hip, knee are most commonly involved in TB arthritis as well as the involvements in this study. ${ }^{23}$ TB peritonitis is not common in childhood and may develop due to miliary TB or neighborhood transmission. ${ }^{24}$ We made probable TB peritonitis diagnosis based on clinical, radiological, histopathological findings.

Miliary TB develops if there is involvement of two or more organs as a result of the hematogenous spread of TB bacilli. In individuals with an uncompromised immune system, $1-2 \%$ of the TB cases are of the miliary type. ${ }^{25}$ In this study, the higher rate of miliary TB was attributed to the sample consisting of pediatric patients.

A TB diagnosis can be bacteriologically proven in less than $50 \%$ of children and less than $75 \%$ of infant cases. A definite diagnosis is based on the isolation of $M$. tuberculosis complex in the sputum of children aged five and over and in gastric aspirate or other body fluids in infants, as well as the tissue samples. ${ }^{26}$ The incidence of ARB positivity in this study was $14 \%$ of sputum and $16 \%$ in FGF smears, which are reported as being less than $15 \%$ and $10 \%$, respectively in the literature. ${ }^{27,28}$ In our study, culture positivity was detected in $20 \%$ of sputum and $33 \%$ of FGF specimens. The literature rates are less than $30 \%$ and 30 to $40 \%$, respectively. ${ }^{27}$

Malnutrition in TB patients is very common, and moderate and severe malnutrition are associated with premature mortality. Body weight affects the severity and prognosis of TB disease. Microbial products stimulate the release of proinflammatory mediators and cytokines, leading to weight loss in the host. ${ }^{29}$ Maxitalia et al. reported that the body weight, body fat percentage, and leptin levels were significantly increased at the end of treatment in TB patients that had presented with mild chronic malnutrition at the time of diagnosis..$^{30}$ To the best of our knowledge, our study is the first to address malnutrition among pediatric TB cases in Turkey. In this study, although we observed clinical improvement at the end of treatment, mild or moderate malnutrition continued. This result remined us the importance of supporting TB treatment with the elimination of poor eating habits and nutritional deficiencies, as well as regulation of social environment. 
Small patient population and the retrospective nature are limitations of this study. Lack of mid-arm circumference measurements is anthropometric data limitation. Larger pediatric TB series with long-term follow-up are needed to evaluate nutrition status.

In conclusion tuberculosis is an important child health problem,and it may be complicated with malnutrition. Performing anthropometric measurements, inquiring about patient's diet, monitoring adequate weight gain, eliminating vitamin and mineral deficiencies should not be neglected in pediatric tuberculosis patients. Management of malnutrition should be integrated into the management of tuberculosis.

\section{References}

1. Global Tuberculosis Report 2017. Geneva, World Health Organisation, 2017, http://www.who.int/tb/publications/global_report/en/.

2. Kocabas E. Childhood tuberculosis. In: Ozlu T, Ozcelik U, Koksallar I, ed. Respiratory Tract Infections in Adults and Children. Istanbul, Nobel Publishers; 2014: 459-76.

3. Lönnroth K, Castro KG, Chakaya JM, et al. Tuberculosis control and elimination 2010-50: cure, care, and social development. Lancet 2010; 375: 1814-29.

4. Reference Book for Tuberculosis Control in Turkey, The Republic of Turkey Ministiry of Health, Department of Tuberculosis Control, Ankara, Turkey, http://www.verem.org.tr//kitap.php.

5. Diagnosis of TB in Children, Guidance for National Tuberculosis Programmes on the Management of Tuberculosis in Children, World Health Organisation, Geneva, Switzerland, 2014, http://apps.who.int/medicinedocs/documents/s21535en/s21535en.pdf.

6. Salazar GE, Schemilz TL, Cama R, et al; Working Group on TB in Peru. Pulmonary tuberculosis in children in a developing country. Pediatrics 2001; 108: 448-53.

7. Kasapkara CS. Protein Energy Malnutrition. In: Yurdakok M, ed. Yurdakok Pediatrics. Ankara, Gunes Medical Publishers; 2017: 505-15.

8. Tuberculosis Control in Turkey Report 2015. Ankara, The Republic of Turkey Ministiry of Health, Public Health Institution, 2016, http://tuberkuloz.thsk.saglik.gov.tr.

9. Gocmen A, Cengizlier R, Ozcelik U, Kiper N, Senuyar R. Childhood tuberculosis: a report of 2205 cases. Turkish Journal of Pediatrics 1997; 39: 149-58.

10. Mtabho CM, Irongo CF, Boeree MJ, Aarnoutse RE, Kibiki GS. Childhood tuberculosis in the Kilimanjaro region: lessons from and the fort he TB programme. Tropical Medicine and International Health 2010; 15: 496-501.

11. Turel O, Kazancı S, Gonen I, Aydogmus C, Karaoglan E, Siraneci R. Paediatric tuberculosis at a referral hospital in Istanbul: analysis of 250 cases. BioMed Research International volume 2016, Article ID 6896279, 6 pages. http://dx.doi.org/10.1155/2016/6896279

12. Tanır G, Akın A, Aydemir C, Uner C, Ceyhan I. The diagnosis of definitive or probable tuberculosis and latent tuberculosis infection in children with suspected tuberculosis. Tuberculosis and Thorax 2005; 53: 259-64.

13. Singer-Leshinsky S. Pulmonary tuberculosis. Improving diagnosis and management. JAAPA 2016; 29: 20-5.

14. Del-Castillo-Barrientos H, Centeno-Luque G, Untiveros-Tello A, et al. Clinical presentation of children with pulmonary tuberculosis: 25 years of experience in Lima, Peru. Int J Tuber Lung Dis. 2014; 18: 1066-73.

15. Esposito S, Tagliabue C, Bosis S. Tuberculosis in children. Mediterranean Journal of Hematology and Infectious Diseases 2013, vol 5, Article ID e2013064.

16. Pekcan S, Aslan AT, Kiper N, et al. Multicentric analysis of childhood tuberculosis in Turkey. Turk J Pediatr 2013; 55: 121-9.

17. Buonsenso D, Lancella L, Delogu G, et al. A twenty-year retrospective study of pediatric tuberculosis in two tertiary hospitals in Rome. Pediatric Infectious Disease Journal 2012; 31: 10226. 
18. Wu XR, Yin QQ, Jiao AX, et al. Pediatric tuberculosis at Beijing Children's Hospital: 2002-2010. Pediatrics 2012; 130: 433-40.

19. Trunz BB, Fine $P$, Dye C. Effect of BCG vaccination on childhood tuberculosis meningitis and miliary tuberculosis worldwide: a metaanalysis and assessment of costeffectiveness. Lancet 2006; 367: 1173-80.

20. Gencer H, Dalgıc N, Kafadar I, Kabakcı D, Oncul U. Retrospective evaluation of 35 pediatric tuberculosis cases proven by histopathological and/or microbiological analysis. J Pediatr Inf 2015; 9: 97-101.

21. Shrestha S, Bichha RP, Sharma A, Upadhyay S, Rijal P. Clinical profile of tuberculosis in children. Nepal Med Coll J 2011; 13: 119-22.

22. Starke JR. Tuberculosis. In: Kliegman RM, Stanton BF, St.Geme JW, Schor NF, Behrman RE, eds. Nelson Textbook of Pediatrics $19^{\text {th }}$ Edition. Elsevier; 2015: 996-1011.

23. Prapruttam D, Hedgire SS, Mani SE, Chandramohan A, Shyamkumar NK, Harisinghani M. Tuberculosis the great mimicker. Semin Ultrasound CTI MRI. 2014; 35: 195-214.

24. Sanai FM, Bzeizi KI. Systematic review: tuberculosis peritonitis-presenting features, diagnostic strategies and treatment. Aliment Pharmacol Ther. 2005; 22: 685-700.

25. Peto HM, Pratt RH, Harrington TA, LoBue PA, Armstrong LR. Epidemiology of extrapulmonary tuberculosis in the United States, 1993-2006. Clin Infect Dis. 2009; 49: 1350-7.

26. American Academy of Pediatrics. Tuberculosis. In: Red Book: 2015 Report of the Committee on Infectious Diseases, zoth ed, Kimberlin DW, Brady MT, Jackson MA, Long SS, eds. American Academy of Pediatrics, Elk Grove Village, IL 2015. p.805.

27. Zar HJ, Hanslo D, Apolles P, Swingler G, Hussey G. Induced sputum versus gastric lavage for microbiological confirmation of pulmonary tuberculosis in infants and young children: a prospective study. Lancet 2005; 365:130-4.

28. Starke JR. Pediatric tuberculosis: time for a new approach. Tuberculosis 2003; 83: 208-12.

29. Pavan Kumar N, Anuradha R, Andrade BB, et al. Circulating biomarkers of pulmonary and extrapulmonary tuberculosis in children. Clin Vaccine Immunol 2013; 20:704-11.

30. Mexitalia M, Dewi YO, Pramono A, Anam MS. Effect of tuberculosis treatment on leptin levels, weight gain, and percentage body fat in Indonesian children. Korean J Pediatr 2017; 60:118-23. 